ElżBieta Hanna Morawska

Uniwersytet Kardynała Stefana Wyszyńskiego

\title{
PARADYGMAT ZAKAZU ZŁEGO TRAKTOWANIA W KONTEKŚCIE KARY DOŻYWOTNIEGO POZBAWIENIA WOLNOŚCI (ARTYKUŁ 3 EUROPEJSKIEJ KONWENCJI PRAW CZŁOWIEKA)
}

\section{WPROWADZENIE}

1. Zgodnie z art. 3 Konwencji o ochronie praw człowieka i podstawowej wolności (konwencja/EKPC) „nikt nie może być poddany torturom ani nieludzkiemu lub poniżającemu traktowaniu albo karaniu"'. Powyższy zakaz ma charakter absolutny, czyli jest zakazem bezwzględnym i bezwarunkowym ${ }^{2}$. Dodatkowo, wynikające z niego zobowiązania dla państw-stron EKPC nie mogą podlegać derogacji nawet „w przypadku wojny lub innego niebezpieczeństwa publicznego zagrażającego życiu narodu" (art. 15 ust. 1 i 2 EKPC).

1 Convention for the Protection of Human Rights and Fundamental Freedoms (CETS No.: 005) z 4 listopada 1950 r.; konwencja powszechnie zwana jest europejską Konwencją praw człowieka (European Convention on Human Rights); konwencja weszła w życie 3 października 1953 r.; Polska ratyfikowała EKPC 19 stycznia 1993 r. (Dz. U. Nr 61, poz. 284).

2 Por. E.H. MORAWSKA, The complex structure of the absolute prohibition of torture. Comments in the light of the regulation of article 3 of the European Convention on Human Rights, «Espaço Jurídico: Journal of Law» 17.3/2016, s. 767-778. 
Na mocy Protokołu nr 11 do EKPC (P-1) art. 3 został zatytułowany „Zakaz tortur”3. Z analizy orzecznictwa organów konwencji, a więc Europejskiej Komisji Praw Człowieka (Komisja/EKomPC) oraz Europejskiego Trybunału Praw Człowieka (Trybunał/ETPC) ${ }^{4}$, wynika wszelako, że wyszły one poza ten jednostkowy wymiar art. 3 traktowania i karania, bowiem rozróżniły tortury od nieludzkiego traktowania albo karania oraz poniżającego traktowania albo karania. Dodatkowo wprowadziły do orzecznictwa termin „złe traktowanie” (ill treatment), obejmując nim wszystkie trzy formy tego traktowania. W świetle orzecznictwa wskazane formy złego traktowania mogą występować samodzielnie ${ }^{5}$ i mają w równym stopniu charakter absolutny ${ }^{6}$, choć szczególne piętno potępienia (special stigma) powiązane zostało z torturami ${ }^{7}$.

2. O złym traktowaniu można mówić, jeśli dane traktowanie spełnia przesłanki jego zaistnienia oraz gdy przekracza poziom dotkliwości, który jest dopuszczalny i nieunikniony, a zarazem jest najniższy z możliwych w danej sytuacji. Dlatego określany jest jako minimalny poziom dopuszczalnej dotkliwości (minimum level of severity) ${ }^{8}$. Przedmiotowe kryterium jest centralnym elementem oceny danej sytuacji pod kątem zakazu złego traktowania. Ocena, czy doszło do jego przekroczenia,

3 Protocol No. 11 to the Convention for the Protection of Human Rights and Fundamental Freedoms, restructuring the control machinery established thereby (CETS/ETS: No. 155) z 11 maja 1994 r. Protokół wszedł w życie 1 listopada 1998 r.; Polska ratyfikowała Protokół 20 maja 1997 r. (Dz. U. z 1998 r. Nr 147, poz. 962-963).

4 Na mocy Protokołu nr 11 do EKPC Komisja zakończyła swoją działalność, a Trybunał został jedynym organem orzeczniczym EKPC.

5 Por. sprawy: Ireland $v$. the UK, nr 5310/71, wyrok z 18 stycznia 1978 r.; Keenan $v$. the UK, nr 2738/95, wyrok z 18 stycznia 2001 r., pkt 110; Renolde v. France, nr 5608/05, wyrok z 16 października 2008 r., pkt 120-121.

6 Sprawa Bekos and Koutropoulos v. Greece, nr 15250/02, wyrok z 13 grudnia 2005 r., pkt 45 .

7 Por. w tym kontekście stanowisko członków EKomPC: H.G. Schermers, G. Batliner, H. Vandenberghe i B. Hall, którzy przestrzegali przed zbyt szeroką wykładnią terminu tortury; odmienny pogląd zajął A. CASsEse, Prohibition of Torture and Inhuman or Degrading Treatment of Punishment, [w:] The European System for the Protection of Human Rights, eds. R.St.J. Macdonald, F. Matscher, H. Petzold, Dordrecht 1993, s. 225 .

Sprawa Ireland v. the UK, nr 5310/71, wyrok z 18 stycznia 1978 r., pkt 162. 
zależy od wielu czynników. Niektóre z tych czynników mają charakter subiektywny, inne obiektywny, zawsze jednak są one odnoszone do danej konkretnej sytuacji. Trybunał bierze pod uwagę między innymi czas trwania złego traktowania, jego fizyczne lub psychiczne skutki dla ofiary, a także jej płeć, wiek oraz zdrowie. Należy mieć również na uwadze, że poziom dopuszczalnej i nieuniknionej w danej sytuacji dotkliwości jest dopasowywany do specyfiki tej sytuacji ${ }^{9}$.

To kontekstowe podejście do zakazu złego traktowania Trybunał uznaje za zgodne z przedmiotem i celem konwencji jako wyrażające dążenie do zapewnienia osobie poddawanej temu traktowaniu rzeczywistej i skutecznej ochrony. Wynikające z tego faktu uzależnienie od specyfiki danej sprawy nie podważa bezwzględnego charakteru przedmiotowego zakazu - wręcz przeciwnie, stanowi dyrektywę wykładni konwencji, która prowadzi do stopniowego poszerzania zakresu obowiązywania art. 3 EKPC. Jednym z wielu obszarów aktywności państw-stron EKPC , w którym to ma miejsce, jest polityka karna. Należy zauważyć, że jest to obszar dotychczas uznawany za nieodłączny element suwerenności państwa i jako taki podlegający wyłącznie wewnętrznym procesom decyzyjnym danego państwa ${ }^{10}$.

9 Przykładowo, Trybunał założył, że z pozbawieniem wolności wiąże się niepokój i trudności (distress or hardship), skutkujące pewnym nieuniknionym cierpieniem. Zostało ono uznane za inherentną właściwość detencji (unavoidable level of suffering inherent in detention) i za nieodłączny jej element. Por. sprawa Kudła v. Poland [WI], nr 30210/96, wyrok z 26 października 2000 r., pkt 94 mutatis mutandis. Szerzej na ten temat por. E.H. Morawska, Sprawa Kudła v. Poland z 2000 r.: typy zobowiazań pozytywnych państw stron europejskiej Konwencji praw człowieka w warunkach detencji (art. 3 konwencji), [w:] Polska przed Europejskim Trybunałem Praw Człowieka. Sprawy wiodące: sprawa Kudła przeciwko Polsce z 2000 r., red. E.H. MoRawsKa, Warszawa 2019, s. 41 i n.

10 Szerzej o relacji pomiędzy suwerennością a prawami człowieka por. F. CAPOTORTI, Human Rights: the Hard Road Towards Universality, [w:] The Structure and Process of International Law: Essays in Legal Philosophy Doctrine and Theory, eds. R.ST.J. MacDonald, D.M. Johnston, Dordrecht-Boston-London 1991, s. 977-1000; szerzej o suwerenności państw z perspektywy prawa międzynarodowego por. R. KwIEcień, Suwerenność państw: rekonstrukcja i znaczenie idei w prawie międzynarodowym, Kraków 2004; por. też np. sprawę Achour v. France [WI], nr 67335/01, wyrok z 29 marca 2006 r., pkt 44. 
Na powyższy proces należy spojrzeć przez pryzmat skutków, rozpoczętej po II wojnie światowej instytucjonalizacji praw człowieka w prawie międzynarodowym. W powszechnej opinii traktaty praw człowieka, wsparte ideą uniwersalizmu praw i zasadą ludzkiej godności, doprowadziły do przełamania bariery, jaka od dawien dawna istniała między prawem międzynarodowym (jako prawem zewnętrznym) a prawem krajowym (jako prawem wewnętrznym) ${ }^{11}$ i w konsekwencji tego do redefinicji zasady suwerenności państwa ${ }^{12}$. Nie miało chodzić przy tym o ubezwłasnowolnienie państwa, lecz o nałożenie nań obowiązku uwzględniania praw człowieka w prawotwórstwie i praktyce krajowej, a nadto poddanie go kontroli międzynarodowej, przynajmniej $\mathrm{w}$ minimalnym stopniu ${ }^{13}$.

3. Ramy analizy, dokonanej w niniejszym artykule, wyznaczają trzy złożone problemy badawcze. Pierwszy z nich, zakreślony we wprowadzeniu, wiąże się ze złożoną strukturą zakazu złego traktowania i stopniem jego bezwzględności oraz bezwarunkowości. Z kolei drugi powiązany jest z zakresem przedmiotowym praw osób skazanych na karę dożywotniego pozbawienia wolności, które Trybunał wywiódł $\mathrm{z}$ art. 3 EKPC. Natomiast trzeci dotyka zobowiązań państw-stron wynikających z przedmiotowych praw, a więc ich charakteru, przedmiotu i środków ich wykonywania.

Rozwiązanie tych problemów badawczych wymagało postawienia wielu szczegółowych hipotez badawczych. Antycypując jednak dalsze uwagi, można stwierdzić, że w ujęciu koncepcyjnym powyższe problemy badawcze są ściśle związane z „zasadą godności każdej osoby ludzkiej”,

${ }^{11}$ A.Z. Drzemczewski, European Human Rights Convention in Domestic Law: a Comparative Study, Oxford 1983, s. 466 i n.

12 A. Peters, Humanity as the $A$ and $\Omega$ of Sovereignty, "European Journal of International Law» 20.3/2009, s. 514.

13 Szerzej na temat tego procesu por. A. MoRAVCsIK, The Origins of Human Rights Regimes: Democratic Delegation in Postwar Europe «International Organization» 54.2/2000, s. 217-252; A. Peters, Humanity..., s. 514; Сн. Tomuschat, International Law: Ensuring the Survival of Mankind on the Eve of a New Century. General Course on Public International Law, «Recueil des Cours: Collected Courses of the Hague Academy of International Law» 281/1999, s. 11. 
jako jednego $\mathrm{z}$ fundamentów mechanizmu konwencji ${ }^{14}$. Państwa-strony EKPC zostały zobligowane do sprawowania wymiaru sprawiedliwości w sprawach karnych w sposób, który da się pogodzić z poszanowaniem ludzkiej godności ${ }^{15}$.

Nie wchodząc w szczegóły wykładni zasady ludzkiej godności w porządku prawnym EKPC, warto zwrócić uwagę, że w orzecznictwie jest ona odczytywana przez pryzmat jej klasycznego, liberalnego ujęcia i jako taka jest ściśle łączona z zasadą wolności i autonomii jednostki ${ }^{16}$.

W uzupełnieniu tak zakreślonych ram artykułu należy również podkreślić, że jego przedmiotem jest stanowisko Trybunału, zajęte w trakcie „rozpoznawania spraw dotyczących wykładni i stosowania Konwencji i jej Protokołów" (art. 32 EKPC). W artykule zostały więc użyte terminy, którymi posługuje się Trybunał dla wyrażenia swojego stanowiska. Co do zasady nie są one dopasowywane do instytucji i pojęć charakterystycznych dla prawa czy praktyki konkretnego państwa-strony EKPC, w tym również polskiego prawa karnego, zarówno materialnego, jak i wykonawczego. Ponadto wiele terminów występujących w porządku prawnym EKPC ma znaczenie autonomiczne wobec krajowych regulacji prawnych ${ }^{17}$. Pomimo swej autonomiczności są one pełnoprawnym wzorcem kontroli prawa i praktyki państw-stron EKPC.

14 R. Spano, Deprivation of Liberty and Human Dignity in the Case-Law of the European Court of Human Rights, «Bergen Journal of Criminal Law and Criminal Justice» 4.2/2016, s. 150-166.

15 T. Jasudowicz, Sprawa Kudła v. Poland z 2000 r.: zasada godności człowieka w porzadku prawnym europejskiej Konwencji praw człowieka, [w:] Polska przed Europejskim Trybunałem Praw Człowieka. Sprawy wiodace: sprawa Kudła przeciwko Polsce $z 2000$ r., red. E. H. MorawskA, Warszawa 2019, s. 21-41.

16 Pokazuje to T. Jasudowicz, Sprawa Kudła v. Poland..., s. 21 i n.; por. też A. Dyer, Irreducible Life Sentences: What Difference have the European Convention on Human Rights and the United Kingdom Human Rights Act Made?, «Human Rights Law Review» 16.3/2016, s. 553; szerzej C. O’MAHony, There is no such thing as a right to dignity, «International Journal of Constitutional Law» 10.2/2012, s. 551-574.

17 Przez pojęcie „krajowe regulacje” są rozumiane zarówno prawne klasyfikacje, jak i ich treść oraz skutek wywoływany w prawie krajowym danego państwa. Por. wiodącą w tej kwestii sprawę Perez v. France [WI] nr 47287/99, wyrok z 12 lutego 2004 r., pkt 57. 


\section{PraWA OSÓB SKaZANYCH NA KaRĘ DOŻYWOTNIEgo POZBAWIENIA WOLNOŚCI W ZWIĄZKU Z ZAKAZEM ZŁEGO TRAKTOWANIA}

1. Analiza orzecznictwa strasburskiego pozwala wyróżnić trzy zasadnicze nurty procesu włączania kary dożywotniego pozbawienia wolności do zakresu przedmiotowego art. 3 EKPC. Podmiotami pierwszego nurtu są dzieci. Warto zaznaczyć, że to w odniesieniu do nich Trybunał po raz pierwszy ustalił, że nałożenie tej kary „może stwarzać problem” (may raise problems) na gruncie art. $3^{\prime \prime 18}$. Z kolei drugi nurt dotyczy osób, wobec których toczą się postępowania o ekstradycję lub wydalenie. W tym wypadku chodzi o ich ochronę przed materializacją rzeczywistego i bezpośredniego zagrożenia skazaniem na karę dożywotniego pozbawienia wolności, bez jakiejkolwiek możliwości wcześniejszego zwolnienia, w państwie przyjmującym ${ }^{19}$.

Ostatni, trzeci nurt w orzecznictwie obejmuje dorosłych skazanych. Ze względu na ograniczone ramy artykułu przedmiotem szczegółowej analizy będzie tylko ten nurt orzecznictwa.

2. W przedmiotowym nurcie można wyróżnić kilka etapów. Pierwszy z nich wiąże się ze skargami, w których skarżący, powołując się na szczególne okoliczności: zaawansowany wiek lub zły stan zdrowia, podnosili, że dalsze odbywanie kary dożywotniego pozbawienia wolności staje się wyjątkowo uciążliwe i tym samym sprzeczne z art. 3 EKPC ${ }^{20}$.

18 Por. sprawy: T. v. the UK [WI], nr 24724/94, wyrok z 16 grudnia 1999 r., pkt 99; $V$. v. the UK [WI], nr 24888/94, wyrok z 16 grudnia 1999 r.; Hill v. the UK, nr 19365/02, decyzja z 18 marca 2003 r.; Partington $v$. the UK, nr 58853/00, decyzja z 26 czerwca 2003 r.

19 Por. sprawy: Nivette v. France, nr 44190/98, wyrok z 3 lipca 2001 r.; Einhorn v. France, nr 71555/01, wyrok z 16 października 2001 r.; konstytutywne dla tej kwestii ustalenia Trybunał zawarł w sprawie Soering $v$. the UK, nr 14038/88, wyrok z 7 lipca 1989 r., pkt 88; problematyka ta jest szerzej analizowana w literaturze przedmiotu. Por. np. S. SMET, The 'Absolute" prohibition of torture and inhuman or degrading treatment in Article 3 ECHR: truly a question or scope only?, [w:] Shaping Rights in the ECHR. The Role of the European Court of Human Rights in determining the Scope of Human Rights, eds. E. Brems, J. Gerards, Cambridge 2013, s. 273 i n.

20 Sprawa Sawoniuk v. the UK z 2001 r., pkt The law, pkt 3. 
Rozpatrując te skargi, Trybunał podkreślał, że choć „kwestia odpowiedniego wymiaru kary w dużej mierze jest poza zakresem Konwencji”, to „nie można wykluczyć, że arbitralna i nieproporcjonalnie długa kara może w pewnych okolicznościach wymagać wyjaśnienia na gruncie Konwencji”'21.

Te stwierdzenia dały asumpt Trybunałowi do ustalenia w 2002 r., iż „rzeczywiście nie jest wykluczone, że kara dożywotniego pozbawienia wolności nałożona na osobę dorosłą bez możliwości przedterminowego zwolnienia może wchodzić w zakres art. $3^{\prime 22}$. Na tym etapie ETPC zwracał uwage przede wszystkim na wymagany przez prawo krajowe pozwanego państwa okres odbycia analizowanej kary, , który uprawniał skazanego do ubiegania się o przedterminowe zwolnienie ${ }^{23}$. Obecny etap orzecznictwa Trybunału wyznacza zaś kilka spraw, choć najbardziej aktywistyczne stanowisko Trybunał zajął w sprawie Kafkaris v. Cyprus z 2008 r. $^{24}$, a następnie w sprawie Vinter and Others v. the UK z 2013 r. ${ }^{25}$ Charakterystyczne jest, że wszystkie te sprawy zostały rozstrzygnięte przez Wielką Izbę ETPC i w orzecznictwie mają status spraw wiodących $(\text { (key cases })^{26}$. W każdej z tych spraw Trybunał wprawdzie podtrzymywał swoje wcześniejsze ustalenia, ale zarazem dodawał do nich nowe, które

21 Ibidem.

22 Sprawa Stanford $v$. the UK, nr 73299/01, wyrok z 12 grudnia 2002 r., The Law (b).

23 Przykładowo, w sprawie Stanford Trybunał ustalił, że skarżący mógł ubiegać się o zwolnienie po odbyciu sześciu lat i dziewięciu miesięcy. W związku z tym stwierdził, że nie może uznać, iż po pierwsze „skarżący może skarżyć, że nie miał nadziei na zwolnienie”, a po drugie, że nie może znaleźć żadnych innych podstaw do uznania, że „skarżący był ofiarą traktowania sprzecznego z artykułem 3 konwencji”.

24 Stanowisko ze sprawy Kafkaris Trybunał podtrzymał w kolejnych sprawach, w tym w sprawie Garagin v. Italy, nr 33290/07, decyzja z 29 kwietnia 2008 r.; Streicher v. Germany, nr 40384/04, decyzja z 10 lutego 2009 r.; Iorgov (No.2) v. Bulgaria, nr 36295/02, wyrok z 2 września 2010 r.

25 Natomiast stanowisko $\mathrm{z}$ tej sprawy wyraźnie utrzymał w sprawie Hutchinson v. the UK [WI], nr skargi 57592/08, wyrok z 17 stycznia $2017 \mathrm{r}$.

${ }_{26}$ W pierwszej kolejności jest to sprawa Kafkaris v. Cyprus [WI], nr 21906/04, wyrok z 12 lutego 2008 r.; następnie są to sprawy: Vinter and Others $v$. the UK, [WI], nr 66069/09 e.a., wyrok z 9 lipca 2013 r.; Murray v. Netherlands [WI], nr 10511/10, wyrok z 26 kwietnia 2016 r.; Hutchinson v. the UK z 2017 r.; Marcello Viola v. Italy [WI] (No 2), nr 77633/16, wyrok z 13 czerwca 2019 r. 
odnosiły się zarówno do materialnego, jak i proceduralnego wymiaru analizowanego paradygmatu.

3. Z łącznej analizy tych spraw wynika, że skazanie dorosłej osoby na karę dożywotniego pozbawienia wolności samo w sobie nie jest ani zakazane, ani niezgodne $\mathrm{z}$ konwencją ${ }^{27}$. Natomiast może być uznane za takie wówczas, gdy kara ta nie może zostać zredukowana (irreducible life sentence $)^{28}$. Należy przy tym dodać, że chodzi zarówno o redukowalność de iure (z mocy prawa), jak i de facto (w praktyce) ${ }^{29}$.

$\mathrm{Z}$ powyższym wymogiem Trybunał powiązał dwa dorozumiane prawa skazanych na karę dożywotniego pozbawienia wolności. Pierwszym jest prawo do szansy na zwolnienie (prospect of release), drugim zaś możliwość weryfikacji zasadności dalszego odbywania tej kary (possibility of review) $^{30}$. Przedmiotowe prawa są wprawdzie odrębne, ale zarazem są na tyle ze sobą powiązane, że pozostają we wzajemnej zależności. Jako takie postrzegane są w kategoriach przyznania skazanemu na karę dożywotniego pozbawienia wolności prawa do nadziei $^{31}$. Konsekwentnie, ich sformułowanie nie oznacza, że konwencja gwarantuje prawo do szansy na natychmiastowe zwolnienie (prospect of imminent release), nawet w przypadku naruszenia przez pozwane państwo art. $3 \mathrm{EKPC}^{32}$. Zakres praw wywiedzionych z zakazu złego traktowania skazanych na dożywotnie pozbawienie wolności należy bowiem odczytywać przez pryzmat wymogu redukcji de iure i de facto

27 Sprawa Kafkaris v. Cyprus z 2008 r., pkt 97.

28 Por. i.a. sprawa Kafkaris v. Cyprus z 2008 r., pkt 97 i we wcześniejszych sprawach: Nivette v. France z 2001 r.; Einhorn v. France z 2001 r.; Stanford v. the UK z 2002 r.; Wynne v. the UK, nr 67385/01, wyrok z 22 maja 2003 r.

29 Sprawa Kafkaris v. Cyprus z 2008 r., pkt 97-98.

30 Ibidem, pkt 98.

31 Podobnie przedmiot tego prawa odczytuje np. sędzia A. Power-Forde, zauważając, że prawo to „nie idzie dalej”, a odmawianie możliwości korzystania z tego prawa skazanym na dożywocie oznaczałoby zaprzeczenie fundamentalnemu aspektowi ich człowieczeństwa, co byłoby poniżające. Por. opinia zbieżna sędzi A. Power-Forde; podobnie w opinii zbieżnej, którą złożył sędzia N. Bratza.

32 Sprawa Harakchiev and Tolumovv. Bulgaria, nr 15018/11 i 61199/12, wyrok z 8 lipca 2014 r, pkt 268; Trybunał podkreślił wyraźnie ten fakt ostatnio w sprawie Marcello Viola v. Italy [WI] (No 2) z 2019 r. 
kary dożywotniego pozbawienia wolności: kara ta jest redukowalna, o ile skazani mają rzeczywistą szansę na ubieganie się o przedterminowe zwolnienie i prawo do weryfikacji zasadności jej dalszego odbywania.

Z prawami tymi powiązany jest obowiązek państw-stron budowy „mechanizmu zapewniającego weryfikację możliwości zwolnienia poprzez ocenę zasadności jej pełnego odbycia”. Trybunał ma na uwadze przedmiotowy mechanizm, a nie usunięcie kary dożywotniego pozbawienia wolności z prawa wewnętrznego państw-stron EKPC. Tym bardziej że chodzi w nim o danie szansy, a nie o zapewnienie zwolnienia ${ }^{33}$. Poza tym skazanie na karę dożywotniego więzienia albo odbycie jej w całości nie jest samo w sobie sprzeczne $\mathrm{z}$ art. 3 EKPC $^{34}$. Państwa-strony mają margines swobody (margin of appreciation) w ustalaniu warunków redukcji kary dożywotniego więzienia, chociaż sprawa Mario Viola v. Italy z 2019 r. pokazuje, że warunki te nie mogą być nadmiernie restrykcyjne ${ }^{35}$.

Wymóg redukowalności de iure i de facto kary dożywotniego pozbawienia wolności obejmuje wszystkich skazanych, niezależnie od tego, jak bardzo są zdeprawowani i jak poważne przestępstwo popełnili. To zaś oznacza, że wszyscy skazani powinni mieć dostęp do wskazanego mechanizmu.

\section{ZOBOWIĄZANIA PAŃSTW-STRON EKPC W ZAKRESIE KARY DOŻYWOTNIEGO POZBAWIENIA WOLNOŚCI}

1. Przechodząc do ostatniego problemu badawczego, należy jeszcze raz mocno podkreślić, że Trybunał nie kwestionuje kary dożywotniego pozbawienia wolności jako takiej ${ }^{36}$. Co więcej, dostrzega zasadność pełnego jej odbycia, o ile skazani odbywający taką karę nadal stanowią zagrożenie dla społeczeństwa ${ }^{37}$. Generalnym obowiązkiem państw-stron

\footnotetext{
33 Sprawa László Magyar v. Hungary, nr 73593/10, wyrok z 20 maja 2014 r., pkt 72.

34 Sprawa Garagin v. Italy z 2008 r.

35 Sprawa László Magyar v. Hungary z 2014 r., pkt 46.

36 Sprawa Vinter and Others v. the UK z 2013 r., pkt 106.

37 Ibidem, pkt 108.
} 
wynikającym z konwencji jest bowiem ochrona społeczeństwa przed przestępczością związaną z użyciem przemocy ${ }^{38}$.

Niemniej powyższy obowiązek nie zwalnia państw-stron z zapewnienia odbywającym karę dożywocia rzeczywistej, a więc istniejącej obiektywnie, szansy na zwolnienie (real prospect of release) ${ }^{39}$. Dlatego Trybunał zobowiązał państwa-strony do stworzenia mechanizmu zapewniającego takim osobom możliwości ubiegania się o zwolnienie poprzez weryfikację zasadności pełnego odbycia tej kary ${ }^{40}$. Mechanizm ten ma więc charakter proceduralny (procedural review mechanism) i państwa-strony mają margines swobody (margin of appreciation) w zakresie formy i charakteru (czy w ramach władzy wykonawczej, czy władzy sądowniczej) tego mechanizmu ${ }^{41}$. Składające się na ten mechanizm procedury nie mogą być jednak iluzoryczne lub teoretyczne, ale muszą być rzeczywiste i skuteczne w danej sprawie ${ }^{42}$. Ten wymóg obiektywizacji (rzeczywistego istnienia) i konkretyzacji (w danej sprawie) skuteczności przedmiotowych procedur przekłada się na szczegółowe wymagania ${ }^{43}$.

Po pierwsze więc, weryfikacja zasadności odbywania kary dożywotniego pozbawienia wolności powinna być regularnie powtarzana w trakcie odbywania tej kary ${ }^{44}$. Po drugie nie może być podyktowana „przypadkami i okolicznościami wyjątkowymi lub nadzwyczajnymi”,

38 Ibidem, pkt 104.

39 Ibidem, pkt 129.

40 Zasady jego funkcjonowania określiła Wielka Izba ETPC w sprawie Vinter and Others v. the UK z 2013 r.; por. też D. van Zyl Smit, P. Weatherby, S. Creighton, Whole Life Sentences and the Tide of European Human Rights Jurisprudence: What Is to Be Done?, «Human Rights Law Review» 14/2014, s. 61.

${ }^{41}$ Sprawa Vinter and Others $v$. the UK, pkt 120; przykładowo, w sprawie Lorgov ETPC uznał, że nie doszło do naruszenia art. 3 EKPC tylko dlatego, że jedynym sposobem możliwości weryfikacji odbywania kary dożywotniego więzienia była instytucja ułaskawienia przez prezydenta. Sprawa Lorgov v. Bulgaria ( $N r$ 2), nr 36295/02, wyrok z 2 września 2010 r., pkt 52, 60.

42 Szerzej o zasadzie skuteczności w porządku prawnym EKPC por. E.H. Morawska, Zobowiązania pozytywne..., s. 113-125.

${ }_{43}$ Sprawa Vinter and Others $v$. the UK z 2013 r., pkt 119, 129.

44 Sprawa Murray v. the Netherlands z 2016 r., pkt 101-103; wcześniej w sprawie Vinter and Others v. the UK z 2013 r., pkt 59-81; por. też C. DJEFAL, Static and Evolutive Treaty Interpretation. A Functional Reconstruction, Cambridge 2016, s. 272-344. 
takimi jak zły stan zdrowia, inwalidztwo skazanego albo jego podeszły wiek. Musi być oparta na wcześniej ustalonych i obiektywnych, a więc niezależnych od indywidualnych cech skazanego, kryteriach. Dlatego skazany na karę dożywocia ma prawo wiedzieć „od samego początku jej odbywania, co musi zrobić, aby móc ubiegać się o zwolnienie i na jakich warunkach" ${ }^{\prime 4}$. Te ramy czasowe determinują moment, w którym dochodzi do ewentualnej niezgodności działań albo zaniechań państw-stron $\mathrm{z}$ art. 3 EKPC. Powstaje ona $\mathrm{w}$ chwili skazania, a nie na etapie jej odbywania ${ }^{46}$.

Dodatkowo przesłanki jej przeprowadzenia nie mogą być niedookreślone. Skutkuje to bowiem brakiem wystarczającej jasności i pewności (sufficient degree of clarity and certainty) i tym samym drastycznym poszerzeniem luzu decyzyjnego władz ${ }^{47}$. Przez pryzmat nakazu wystarczającej jasności weryfikacji należy odczytać obowiązek władz uzasadniania i upubliczniania podejmowanych decyzji ${ }^{48}$, następnie dokonywania ich w oparciu o jasno określone zasady i dostateczne gwarancje proceduralne ${ }^{49}$.

W ocenie, na ile powyższy mechanizm zapewnia realne szanse na przedterminowe zwolnienie (real prospect of release de facto), Trybunał wykorzystuje dane statystyczne o dokonanych redukcjach kary dożywotniego pozbawienia wolności w pozwanym państwie-stronie ${ }^{50}$. Ta praktyka wymaga podkreślenia, ponieważ Trybunał wyjątkowo ostrożnie sięga po tego typu dane. Jak wiadomo, najszerzej dopuszcza je w przypadku zarzutu naruszenia zakazu dyskryminacji, uznając, że mogą one być wystarczające do przeniesienia ciężaru dowodu na

\footnotetext{
45 Sprawa Vinter and Others $v$. the UK z 2013 r., pkt 122.

46 Ibidem.

47 Sprawa Petukhov v. Ukraine (No. 2), nr 41216/13, wyrok z 12 marca 2019 r., pkt 175.

48 Ibidem, Pkt 178.

49 Ibidem, pkt 179; przedmiotem dyskusji w piśmiennictwie jest, czy chodzi w tym wypadku o gwarancje habeas corpus (art. 5 ust. 4 EKPC). Por. R. Spano, Deprivation of Liberty..., s. 161-162; szerzej D. Smit van Zy L, P. Weatherby, S. Creighton, Whole Life Sentences and the Tide of European Human Rights Jurisprudence: What Is to Be Done?, «Human Rights Law Review» 14/2014, s. 59-84.
}

50 Sprawa Petukhov v. Ukraine (No. 2) z 2019 r., pkt 185-186. 
pozwane państwo-stronę ${ }^{51}$. W odniesieniu do kary dożywotniego pozbawienia wolności podejście Trybunału do tych danych jest zdecydowanie bardziej rozważne. Stwierdza bowiem, że dane statystyczne o wykorzystywaniu mechanizmu weryfikacji zasadności odbywania kary dożywotniego pozbawienia wolności mogą być wzięte pod uwage tylko w ocenie redukowalności de facto tej kary ${ }^{52}$.

2. W zakresie zaś podstaw materialnych mechanizmu weryfikacji zasadności dalszego odbywania kary dożywocia należy podkreślić, że musi być ona przeprowadzana w oparciu o uzasadnione względy penologiczne (legitimate penological grounds), takie jak: ukaranie, odstraszanie, bezpieczeństwo publiczne oraz resocjalizacja ${ }^{53}$. Podczas każdej omawianej weryfikacji względy te powinny być brane pod uwagę, choć szczególne znaczenie Trybunał nadał resocjalizacji ${ }^{54}$.

Nie chodzi przy tym o indywidualne rozwiązania, ale o zapewnienie więźniom odbywania kary w reżimach więziennych, opartych na resocjalizacji i umożliwiających osiąganie postępów w tym zakresie ${ }^{55}$. To zaś oznacza nałożenie na państwa-strony konkretnego zobowiązania pozytywnego, mianowicie zobowiązania zaoferowania (więźniom) rzeczywistej możliwości poddania się działaniom resocjalizacyjnym (obligation to offer a real opportunity to rehabilitate themselves) ${ }^{56}$. Ponieważ z zobowiązania tego nie może wynikać dla władz nadmierny ciężar, przedmiotowy obowiązek jest obowiązkiem środków (oczekiwanych działań),

51 Por. sprawę Konstantin Markin v. Russia [WI], nr 30078/06, wyrok z 22 marca 2012 r.; ETPC sięga po tego typu dane w szczególności odnośnie do dyskryminacji mniejszości romskiej. Sprawą podstawową w tym zakresie jest sprawa D.H. and Others v. the Czech Republik [WI], nr 57325/00, wyrok z 13 listopada 2007 r.; szerzej na ten temat por. C. Hermida del Llano, Argumentation of the Court of Strasbourg's Jurisprudence regarding the discrimination against Roma "Przegląd Prawa Konstytucyjnego» 6.28/2015, s. 11-38.

52 Sprawa Petukhov v. Ukraine (No. 2) z 2019 r., pkt 185; podobnie we wcześniejszych sprawach, np. Murray v. the Netherlands z 2016 r., pkt 100.

53 Sprawa Murray v. the Netherlands z 2016 r., pkt 102.

${ }^{5}$ Ibidem.

55 Ibidem, pkt 104.

56 Ibidem, pkt 103. 
a nie rezultatu ${ }^{57}$. Ponadto w wyborze tych środków państwa-strony mają szeroki margines swobody ${ }^{58}$ i nie ponoszą odpowiedzialności za brak postępów w resocjalizacji w przypadku konkretnych więźniów ${ }^{59}$.

W uzasadnieniu nałożenia na państwa-strony przedmiotowego obowiązku Trybunał wskazał explicite zasadę ludzkiej godności ${ }^{60}$. Stwierdził więc, że „pozbawienie człowieka jego wolności bez dążenia do jego resocjalizacji i zapewnienia mu możliwości odzyskania tej wolności w przyszłości byłoby niezgodne z ludzką godnością - która leży u podstaw całego systemu Konwencji"61. W innym zaś miejscu Trybunał przypomniał, że w społeczeństwie, którego filarem jest ludzka godność, resocjalizacja skazanego jest konieczna ${ }^{62}$.

Podstawy normatywne dla, jak to Trybunał ujmuje, zasady resocjalizacji (principle of rehabilitation) znajdować się mają nie tylko w art. 3 EKPC, lecz także w innych postanowieniach konwencji, w tym w szczególności w art. 8 EKPC, stanowiącym o prawie do poszanowania życia prywatnego i rodzinnego ${ }^{63}$.

Wskazane przepisy nie stanowią o zasadzie rehabilitacji explicite. Co więcej, nie stanowią również o ludzkiej godności, gdyż jedyne bezpośrednie odwołanie do niej zawiera preambuła Protokołu nr 13 do EKPC, stanowiąc, że „zniesienie kary śmierci jest niezbędne dla ochrony [prawa każdego do życia] i pełnego uznania wrodzonej godności każdej istoty ludzkiej"64.

57 Sprawa Petukhov v. Ukraine (No. 2) z 2019 r., pkt 181-182; wcześniej m.in. w sprawie Harakchiev and Tolumov v. Bulgaria z 2014 r., pkt 264.

58 Sprawa Murray v. the Netherlands z 2016 r., pkt 110.

59 Ibidem, pkt 104.

60 Sprawa Murray v. the Netherlands z 2016 r., pkt 103-104; por. też sprawę Hirst v. the UK (No. 2) [WI], nr 74025/01, wyrok z 6 października 2005 r., pkt 69-70; szerzej por. np. A. Kuteynikov, A. Boyashov, Diginity before the European Court of Human Rights, [w:] Human dignity. Establishing Worth and Seeking Solutions, red. E. SiEH, J. MCGregor, London 2017, s. 93-104.

61 Sprawa Murray v. the Netherlands z 2016 r., pkt 101.

62 Ibidem.

63 Ibidem, pkt 102.

64 Protocol No. 13 to the Convention for the Protection of Human Rights and Fundamental Freedoms, concerning the abolition of the death penalty in all circumstances 
To kontekstowe osadzenie zasady ludzkiej godności jest charakterystyczne dla porządku prawnego EKPC. Jest powiązane z jej funkcjonalno-pragmatycznym postrzeganiem przez Trybunał. W analizowanym zakresie chodzi o ukazanie, że nieredukowalne kary dożywotniego pozbawienia wolności „lekceważą człowieczeństwo osób osadzonych i oznaczają ich przedmiotowe traktowanie" ${ }^{35}$.

Wprawdzie Trybunał wyraźnie zastrzega, że „Konwencja nie gwarantuje jako takiego prawa do resocjalizacji”, ale jednocześnie zauważa, że „osoby skazane, w tym również skazane na karę dożywotniego pozbawienia wolności, powinny mieć możliwość resocjalizacji”66. Tylko wówczas przedmiotowa kara może zostać uznana za karę redukowalną de facto $^{67}$. Obowiązek zapewniania warunków umożliwiających resocjalizację jest zatem funkcjonalnie powiązany $\mathrm{z}$ wymogiem redukowalności tej kary: postęp w resocjalizacji zwiększa szanse więźnia na „zamianę, umorzenie lub rozwiązanie dożywocia lub przedterminowe zwolnienie" ${ }^{\prime 68}$.

3. W świetle przedstawionych ustaleń Trybunału zasadne jest pytanie o ich główny cel. Wydaje się, że chodzi o europejski paradygmat polityki karnej państw-strony EKPC, którego obligatoryjnym elementem (mandatory factor) ${ }^{69}$ ma być umożliwienie osadzonym rzeczywistej resocjalizacji ${ }^{70}$. To spostrzeżenie zasługuje na uwagę, zważywszy na stwierdzenie Trybunału, że choć „cel uwięzienia jest postrzegany nadal przez pryzmat odpłaty (ukarania) za popełnione przestępstwo,

(ETS: No. 187) z 3 maja 2002 r.; Polska ratyfikowała ten protokół 23 maja 2014 r. (Dz. U., poz. 1155).

65 R. Spano, Deprivation of Liberty and Human Dignity..., s. 154.

66 Sprawa Murray v. the Netherlands z 2016 r., pkt 103; podobnie w sprawie Polyakova and Others v. Russia, nr 35090/09 e.a., wyrok z 7 marca 2017 r., pkt 88.

67 Sprawa Murray v. the Netherlands z 2016 r., pkt 125.

68 Ibidem, pkt 104.

69 Sprawa Hutchinson v. the UK z 2017 r., pkt 43.

70 Na kwestię tę zwrócił uwagę sędzia K. WoJTYCzEK w swej opinii rozbieżnej z wyrokiem ETPC w sprawie Marcello Viola v. Italy z 2019 r. 
to obecnie europejska polityka karna kładzie nacisk na resocjalizację uwięzionych, w szczególności pod koniec długoletniego więzienia"71.

Jest to wszelako nacisk, który nie oznacza odrzucenia innych „uzasadnionych względów penologicznych" i zakwestionowania wykonywania przez państwa-strony EKPC „pozytywnego obowiązku ochrony społeczeństwa przed przestępczością z użyciem przemocy (obligation to protect the public from violent crime). Konwencja nie zakazuje bowiem odmowy redukcji kary dożywotniego pozbawienia wolności w przypadku osadzonego, który pozostaje niebezpieczny, w szczególności gdy dopuścił się morderstwa lub innego poważnego przestępstwa przeciwko życiu lub zdrowiu. Innymi słowy, osoba taka może pozostać w detencji tak długo jak ,jej postęp poczyniony w resocjalizacji [nie jest na tyle] wystarczający, a dalsza detencja może być nadal usprawiedliwiana [innymi] uzasadnionymi względami penologicznymi"72. Co więcej, chodzi o postęp w możliwości prowadzenia po wyjściu z więzienia „odpowiedzialnego i wolnego od przestępstw życia” (responsible and crime-free life). Koresponduje to, po pierwsze, $\mathrm{z}$ utożsamianiem resocjalizacji z integracją ze społeczeństwem, a po drugie, z jednym z celów resocjalizacji, którym jest zapobieganie ponownemu popełnieniu przestępstwa i tym samym zapewnianie ochrony społeczeństwa ${ }^{73}$.

\section{Podsumowanie}

Z analizy orzecznictwa ETPC wynika, że paradygmat złego traktowania w kontekście kary dożywotniego pozbawienia wolności Trybunał wypracowywał stopniowo, choć czynił to na tyle konsekwentnie,

${ }_{71}$ Sprawa Vinter and Others $v$. the UK z 2013 r., pkt 115; podobne podejście m.in. w sprawie Khoroshenko v. Russia [WI], nr 41418/04, wyrok z 30 czerwca 2015 r., pkt 121, choć na gruncie art. 8 EKPC.

72 Sprawa Vinter and Others $v$. the UK z 2013 r., pkt 113-116 mutatis mutandis.

73 Sprawa Murray v. the UK z 2016 r., pkt 102; w istocie zapobieganie ponownemu popełnieniu przestępstwa jest jedną z „podstawowych funkcji” kary pozbawienia wolności. Por. np. Choreftakis and Choreftaki v. Greece, nr 46846/08, wyrok z 17 stycznia 2012 r., pkt 45. 
że obecnie można uznać go za dobrze ukształtowany ${ }^{74}$. Na jego treść składają się zarówno prawa osób odbywających karę dożywotniego pozbawienia wolności, jak i zobowiązania państw-stron EKPC.

Dokonane ustalenia pozwalają szukać uzasadnienia teoretycznego tego paradygmatu w zasadzie obiektywności zobowiązań państw-stron EKPC, w szczególności na płaszczyźnie relacji wertykalnych (państwo - każda osoba). Dla prowadzonych rozważań najistotniejsza jest przede wszystkim jednostronność tych zobowiązań wobec osób znajdujących się pod jurysdykcją państw-stron (art. 1 EKPC). Status tych osób jako uprawnionych do korzystania z praw i podstawowych wolności nie jest zdeterminowany ich postawą wobec państwa, społeczeństwa albo innych osób ${ }^{75}$. Ten aspekt niewzajemności nabiera szczególnego znaczenia i wyrazistości w odniesieniu do zakazu złego traktowania. Jego poszanowanie nie może być warunkowane postępowaniem danej osoby, nawet wówczas, gdy dokonuje ona czynów naruszających integralność fizyczną i psychiczną czy zagrażających życiu innych osób ${ }^{76}$.

Powyższy aspekt zasady obiektywności koresponduje $\mathrm{z}$ absolutnym charakterem zakazu złego traktowania. W świetle orzecznictwa bowiem zakaz ten nie może zostać naruszony „[...] nawet w najtrudniejszych [dla społeczeństwa demokratycznego] okolicznościach, takich jak walka z terroryzmem czy przestępczością [...]"77. Dlatego Trybunał stwierdza,

74 Por. np. B. Vermeulen, Freedom from Torture and Other Inhuman or Degrading Treatment or Punishment, [w:] Theory and Practice of The European Convention on Human Rights ${ }^{4}$, eds. P. van Dijk, F. van Hoof, A. van Rijn, L. ZwaAk, Antwerpen-Oxford 2006, s. 419 i n.

75 J.H. KNox, Horizontal Human Rights Law, «American Journal of International Law»102/2008, s. 1-41.

76 C. WARBRICK, The European Response to Terrorism in an Age of Human Rights, «European Journal of International Law»15.5/2004, s. 989-1018; J. FITZPATRICK, Speaking Law to Power: the War against Terrorism and Human Rights, «European Journal of International Law» 14.2/2003, s. 241-264; J. Hedigan, The European Convention on Human Rights and Counter-Terrorism, «Finish Journal of International Law» 28.2/2004, s. 392-431.

77 Sprawa Selmouni v. France [WI], nr 25803/94, wyrok z 28 lipca 1999 r., pkt 95. 
że czyny osoby skazanej nie zwalniają państwa-strony z poszanowania tego zakazu, gdyż są one „irrelewantne dla celów artykułu 3”78.

Głównym celem tego zakazu jest ochrona ludzkiej godności oraz fizycznej i psychicznej integralności człowieka ${ }^{79}$. Natomiast szeroko i autonomicznie rozumiana detencja stanowi wyjątkowe zagrożenie dla urzeczywistnienia tych celów ${ }^{80}$. Co więcej, należy przypomnieć, że istotą konwencji jest poszanowanie ludzkiej godności każdej osoby, również osoby skazanej na karę dożywotniego pozbawienia wolności ${ }^{81}$. To oznacza, że jest ona - pomimo skazania - nadal uprawniona do korzystania z konwencyjnych praw i podstawowych wolności, z wyjątkiem oczywiście prawa do wolności osobistej ${ }^{82}$.

W świetle tych uwag zrozumiałe jest powołanie się Trybunału na ludzką godność w paradygmacie traktowania osób skazanych na karę dożywotniego pozbawienia wolności. Jest ona ważnym uzasadnieniem dla konstytuujących ten paradygmat praw tych osób, a więc prawa do szansy na zwolnienie oraz prawa do możliwości weryfikacji zasadności jej dalszego odbywania. Wywiedzenie tych praw oznacza dla państw-stron konieczność odrzucenia w polityce karnej trwałego izolowania i sytuowania skazanych poza społeczeństwem, nawet tych szczególnie zdemoralizowanych, którzy dopuścili się czynów o wysokiej szkodliwości społecznej ${ }^{83}$. Z ludzką godnością nie jest również do pogodzenia

78 Sprawa Chahal v. the UK [WI], nr 22414/93, wyrok z 15 listopada 1996 r., pkt 79.

79 Sprawa Selmouni v. France z 1999 r., pkt 99.

80 Tak chociażby w sprawie Dedovskiy and Others $v$. Russia, nr 7178/03, wyrok z 15 maja 2008 r., pkt 73.

${ }^{81}$ W kontekście zasady godności człowieka w prawie międzynarodowym praw człowieka por. np. B. DE GAAY FORTMAN, Equal dignity in international human rights law, [w:] The Cambridge Handbook of Human Dignity. Interdisciplinary Perspectives, eds. M. Düwell, J. Braarvig, R. Brownsword, D. Mieth, Cambridge 2014, s. 355 364; w kontekście zaś ludzkiej godności więźniów por. D. LuBAN, Treatment of prisoners and torture, [w:] The Cambridge Handbook of Human Dignity. Interdisciplinary Perspectives, eds. M. Düwell, J. Bra arvig, R. Brownsword, D. Mieth, Cambridge 2014, s. 446-454.

82 Sprawa Stummer v. Austria [WI], nr 37452/02, wyrok z 7 lipca 2011 r., pkt 99.

83 M. Konopczyński, Pedagogika resocjalizacyjna, Kraków 2014, s. 17. 
przymusowa, niezakładająca resocjalizacji tych osób, ich izolacja ${ }^{84}$. W swej ocenie reżimów więziennych państw-stron Trybunał podkreśla, że powinny być one ukierunkowane na ludzką godność więźniów, tak aby każdy z nich mógł zdecydować, czy chce poddać się działaniom resocjalizacyjnym i tym samym mieć szansę na spełnienie warunków redukcji odbywanej kary ${ }^{85}$.

Z zasadą resocjalizacji Trybunał powiązał zobowiązanie pozytywne, którego przedmiotem jest stworzenie takich warunków detencji, które będą ułatwiać realizację programów resocjalizacyjnych, opartych na poszanowaniu godności osób skazanych i skutkowały zmianami w obszarze ich samoświadomości, samowychowania, samopotwierdzenia i samorefleksji ${ }^{86}$. Powyższe zobowiązanie występuje wówczas, gdy reżim więzienny czy warunki detencji uniemożliwiają resocjalizację ${ }^{87}$.

Ponieważ państwa-strony mają szeroki margines swobody w wyborze działań (środków) mających umożliwić odpowiednią resocjalizację (proper opportunity for rehabilitation), to Trybunał nie stworzył a piori ich katalogu. Nie ulega jednak wątpliwości, że zależą one od konkretnych sytuacji i muszą być dostosowane do indywidualnych potrzeb więźniów ${ }^{88}$.

W nawiązaniu do wypracowanego przez ETPC paradygmatu złego traktowania w kontekście kary dożywotniego pozbawienia wolności należy zwrócić uwagę na polską ustawę o zmianie ustawy - Kodeks karny oraz niektórych innych ustaw, uchwaloną przez Sejm RP 13 czerwca

84 Sprawa Murray v. the Netherlands z 2016 r., pkt 101.

85 Ibidem, pkt 117.

86 K. PierzchaŁA, Wina - prawo - kara. Prawne i psychologiczne aspekty resocjalizacji penitencjarnej, «Probacja» 3/2017, s. 106.

87 Sprawa Harakchiev and Tolumov v. Bulgaria z 8 lipca 2014.

88 Przykładowo, w sprawie Murray v. the Netherlands z 2016 r. chodziło o umożliwienie resocjalizacji więźniowi z zaburzeniami psychicznymi, natomiast w sprawie Khoroshenko v. Russia [WI], nr 41418/04, wyrok z 30 czerwca 2015 r. chodziło o umożliwienie resocjalizacji w warunkach materialnych detencji naruszających ludzką godność. 
$2019 \mathrm{r}^{89}$ Inicjatorem uchwalenia tej ustawy był rząd ${ }^{90}$. W jej uzasadnieniu stwierdzono, że ma ona ukierunkować „decyzję sądu w stronę ograniczenia możliwości korzystania z redukowania sankcji karnej”, bowiem uznano, że „oczekiwanie, że kara zostanie pozbawiona swojej odstraszającej funkcji i traktowana będzie wyłącznie jako środek społecznej integracji, który prowadzi do akceptacji norm prawnych i w rezultacie do zmiany zachowań społecznych, zdaje się być przejawem czysto idealistycznej aksjologii, nieprzystającej do rzeczywistości" ${ }^{\prime 1}$. Konsekwentnie, stanowi ona, że w ściśle określonych warunkach sąd będzie mógł orzekać w sposób obligatoryjny lub fakultatywny zakaz warunkowego zwolnienia sprawcy z odbycia reszty kary dożywotniego pozbawienia wolności. Jednocześnie podwyższyła zwykłą granicę możliwości warunkowego zwolnienia skazanego na karę dożywotniego pozbawienia wolności z dotychczasowych 25 lat do 35 lat, przy zachowaniu prawa sądu do ustalenia innej wyższej granicy warunkowego zwolnienia skazanego na terminową karę pozbawienia wolności i karę dożywotniego pozbawienia wolności. Dodatkowo, wprowadziła dożywotni okres próby dla warunkowo zwolnionego skazanego na karę dożywotniego pozbawienia wolności.

Powyższe zmiany dopuszczają więc nieredukowalność de iure kary dożywotniego pozbawienia wolności i w rezultacie tego pozbawienie skazanych na karę dożywotniego pozbawienia wolności szansy na zwolnienie (prospect of release) oraz możliwość weryfikacji zasadności jej odbywania (possibility of review). Jak dotąd ustawa ta nie weszła w życie, ponieważ prezydent, ze względu na wątpliwości odnośnie do konstytucyjności procedury jej uchwalenia, skierował ją, w trybie kontroli prewencyjnej, do Trybunału Konstytucyjnego ${ }^{92}$.

W ocenie Prezydenta RP zaproponowany w ustawie kierunek zmian prawa karnego nie budził zastrzeżeń i dawał wyraz „zrozumiałym

89 Została ona uchwalona po uprzednim rozpatrzeniu poprawek Senatu RP. Por. uchwała Senatu RP w sprawie ustawy o zmianie ustawy - Kodeks karny oraz niektórych innych ustaw, druk nr 3473.

90 Druk sejmowy nr 3451.

91 Uzasadnienie - druk sejmowy nr 3451.

92 Wniosek Prezydenta RP w sprawie Kp 1/19. 
dążeniom ustawodawcy do stanowienia przepisów karnych, które odpowiadają wymogom sprawiedliwości" ${ }^{93}$. Niemniej w debacie społecznej zarzucono jej nadmierną represyjność i punitywność ${ }^{94}$. Dodatkowo podnoszono, że odnośnie do redukowalności kary dożywotniego pozbawienia wolności narusza ona minimalny standard przyjęty w wiążących Polskę traktatach praw człowieka ${ }^{95}$, zarówno uniwersalnych, jak i regionalnych ${ }^{96}$.

\section{Ibidem.}

94 Zwracał na to uwagę Rzecznik Praw Obywatelskich w pismach kierowanych do ministra sprawiedliwości - Prokuratora Generalnego, marszałka Senatu RP i Prezydenta RP. Por. pisma i ekspertyzy, odnośnie do wymienionych wyżej nowelizacji: https:// www.rpo.gov.pl/pl/content/zmiany-w-prawie-karnym-2019-opinie-ekspertow-i-RPO (dostęp 3 grudnia 2019 r.); por. też Opinia do uchwały Senatu Rzeczypospolitej Polskiej z dnia 24 maja 2019 r. w sprawie ustawy o zmianie ustawy - Kodeks karny oraz niektórych innych ustaw, uchwalonej przez Sejm Rzeczypospolitej Polskiej na 81. posiedzeniu w dniu 16 maja 2019 r. Jej autorami byli: dr hab. A. Barczak-Oplustil, dr W. Górowski, dr M. Iwański, dr M. Małecki, dr W. Zontek, dr S. Tarapata, dr hab. prof. UJ W. Wróbel. Tekst opinii jest na stronie Krakowskiego Instytutu Prawa Karnego: https://kipk.pl/ analizy/ekspertyzy (dostęp 3 grudnia 2019 r.).

95 T. GARDock A, Opinia zewnętrzna. Autor wskazany przez poseł Barbarę Dolniak, wicemarszałek Sejmu RP. Ekspertyza dotycząca zmian w kodeksie karnym (druk nr 3451 oraz tekst przekazany do Senatu po uchwaleniu przez Sejm 16 maja 2019 roku), http:// www.sejm.gov.pl/sejm8.nsf/opinieBAS.xsp?nr=3451 (dostęp 12 grudnia 2019 r.).

96 Jeśli chodzi o uniwersalny system ochrony praw człowieka to kluczowe znaczenie ma art. 10 Międzynarodowego Paktu Praw Obywatelskich i Politycznych (International Covenant on Civil and Political Rights, United Nations, Treaty Series, vol. 999, s. 171 and vol. 1057, s. 40) z 19 grudnia 1966 r.; Polska ratyfikowała MPPOiP 18 marca 1977 r. (Dz. U. Nr 38, poz. 167); por. też UN Human Rights Committee, General Comment No. 35, Article 9 (Liberty and Security of Person); UN Human Rights Committee, General Comment No. 21: Article 10 (Humane treatment of persons deprived of their liberty); powyższe komentarze Komitetu Praw Człowieka ONZ, https://tbinternet.ohchr.org/ layouts/15/treatybodyexternal/TBSearch.aspx?Lang=en \&TreatyID=8\&DocTypeID=11 (dostęp 23 marca 2020 r.); w kontekście omawianego paradygmatu bardzo ważne są też Wzorcowe Minimalne Reguły Więzienne (Standard Minimum Rules for the Treatment of Prisoners) przyjęte na I Kongresie Narodów Zjednoczonych w sprawie Zapobiegania Przestępczości i Postępowania z Przestępcami i zaakceptowane 31 lipca 1957 r. przez Radę Społeczno-Gospodarczą ONZ rezolucją 663 CI (XXIV) oraz Wzorcowe Reguły Minimalne ONZ dotyczące postępowania z więźniami (Reguły Mandeli) (UN Standard Minimum Rules for the Treatment of Prisoner (The Nelson Mandela Rules), przyjęte 
Zważywszy zarówno na prawo traktatów i porządek prawny konwencji, jak i na polskie prawo konstytucyjne powyższe zastrzeżenia należy uznać za zasadne. Zgodnie z prawem traktatów państwa mają obowiązek wykonywania w dobrej wierze (pacta sunt servanda) zobowiązań wynikających z traktatów, których są stronami. Nie mogą przy tym powoływać się na przepisy prawa krajowego, by usprawiedliwić ich niewykonywanie (zasada prymatu prawa międzynarodowego) ${ }^{97}$. W przypadku zaś porządku prawnego konwencji kluczowe znaczenie ma art. 1 EKPC, stanowiący o zobowiązaniu państw-stron EKPC poszanowania praw człowieka i potwierdzający międzynarodowy charakter tego zobowiązania, następnie art. 19 EKPC, wskazujący cel, dla którego został utworzony Trybunał, a więc zapewnienie przestrzegania przez państwa-strony EKPC zobowiązań wynikających z konwencji, oraz art. 46 EKPC, stanowiący o mocy wiążącej oraz o wykonywaniu wyroków Trybunału, którego jurysdykcję we wszystkich sprawach dotyczących wykładni i stosowania EKPC Polska uznała w 1993 r. ${ }^{98}$

Jeśli zaś chodzi o prawo konstytucyjne, to kluczowe znaczenie ma w kontekście prowadzonych rozważań art. 9 Konstytucji $\mathrm{RP}^{99}$. W literaturze przedmiotu trafnie zwraca się uwagę, że zasada zawarta w tym przepisie ma szerszy wymiar niż zasada pacta sunt servanda z prawa traktatów. Tym samym stanowi nie tylko o prymacie zobowiązań traktatowych, lecz także zobowiązań międzynarodowych wynikających z pozostałych źródeł prawa międzynarodowego ${ }^{100}$.

8 stycznia 2016 r. przez Zgromadzenie Ogólne ONZ rezolucją A/RES/70/175. Szerzej por. Międzynarodowe standardy wykonywania kar, red. T. Szymanowski, «Przegląd Więziennictwa Polskiego» 72-73/2011 (numer specjalny); K. MrozeK, Reguły Nelsona Mandeli, «Nowa Kodyfikacja Prawa Karnego» 68/2081, s. 169-182.

97 Por. art. 26 i 27 konwencji wiedeńskiej o prawie traktatów z 23 marca 1969 r. (Vienna Convention on the Law of Treaties, U N, T S, Vol. 1155, s. 331); Polska ratyfikowała KWPT 2 lipca 1990 r. (Dz. U. Nr 74, poz. 439).

98 Dz. U. Nr 61, poz. 285.

99 Dz. U. z 1997 r. Nr 78, poz. 483 ze zm.

100 Por. np. M. Borski, Miejsce umów międzynarodowych w porządku prawnym Rzeczypospolitej Polskiej, «Rocznik Administracji i Prawa» 16/2016, s. 17-32; L. GARLICKI, I. KondAK, Poland. Human rights between international and constitutional law, [w:] The Impact of the ECHR on Democratic Change in Central and Eastern Europe, eds. 
Zgodnie z zasadą subsydiarności odpowiedzialność za zapewnienie praw i podstawowych wolności gwarantowanych przez konwencję ponoszą państwa-strony EKPC. Porządek prawny konwencji pełni w tym zakresie rolę pomocniczą ${ }^{101}$. Niemniej wykładnia przepisów krajowych, następnie ich stosowanie oraz ich skutki podlegają kontroli Trybunału pod kątem ich zgodności z zasadami konwencji, tak jak są one interpretowane w orzecznictwie ${ }^{102}$.

W piśmiennictwie słusznie podnoszona jest kwestia częstego braku w orzecznictwie Trybunału ,jasnych i czytelnych standardów, które mogłyby stanowić wartościowe wskazówki” odnośnie do wykładni konwencji ${ }^{103}$. Niemniej w przypadku paradygmatu złego traktowania w kontekście kary dożywotniego pozbawienia wolności wskazówki Trybunału wydają się jednoznaczne. Takie sprawy jak Vinter and Others v. the UK z 2013 r., Murray v. the Netherlends z 2016 r. czy Marcello Viola v. Italy z 2019 r. pokazują stanowczość w szczególności Wielkiej Izby we wdrażaniu przedmiotowego paradygmatu. Jest więc wysoce prawdopodobne, że wejście w życie wskazanych przepisów ustawy z 2019 r. spowoduje skargi więźniów odbywających karę dożywotniego pozbawienia wolności na naruszenie przez Polskę art. 3 EKPC. Doprowadzić to może do powstania w mechanizmie konwencji kolejnej kategorii spraw polskich, podobnie jak w przypadku naruszania art. 6 EKPC w związku z przewlekłością postępowań czy art. 3 EKPC w związku z warunkami detencji i przeludnieniem w zakładach karnych.

I. Мотос, I. Ziemele, Cambridge 2016, s. 306-310 wraz z odesłaniami do orzecznictwa i doktryny.

101 Wynika to $\mathrm{z}$ art. 13 oraz art. 35 ust. 1 EKPC; $\mathrm{w}$ tym kontekście por. np. sprawę Scordino v. Italy [WI], nr 36813/97, wyrok z 26 marca 2006 r., pkt 140.

102 Sprawa Scordino v. Italy z 2006 r., pkt 191.

103 Por. np. A. WiśNIewski, Uwagi o zastosowaniu standardów strasburskich w sprawach dotyczących ochrony dóbr osobistych (na tle ostatnich orzeczeń ETPC w sprawach przeciwko Polsce), «Gdańskie Studia Prawnicze» 39/2018, s. 85. 
PARADYgMAT ZAKAZU ZŁEGO TRAKTOWANIA W KONTEKŚCIE KARY DOŻYWOTNIEGO POZBAWIENIA WOLNOŚCI (ARTYKUŁ 3 EUROPEJSKIEJ Konwencji Praw Człowieka)

\section{Streszczenie}

Ramy analizy przeprowadzonej w tym artykule obejmują trzy wieloaspektowe problemy badawcze. Pierwszy z nich wiąże się ze złożoną strukturą przedmiotu zakazu złego traktowania i stopniem jego absolutności: bezwzględnością i bezwarunkowością. Drugi dotyczy materialnego zakresu praw osób skazanych na bezwzględną karę dożywotniego pozbawienia wolności. Natomiast trzeci problem dotyczy struktury i charakteru, treści (przedmiotu) oraz środków wykonywania obowiązków Państwa-Strony, skorelowanych z tymi prawami.

Powyższe trzy problemy badawcze koncentrują się na orzecznictwie organów EKPC w zakresie kary bezwzględnego pozbawienia wolności na gruncie art. 3 EKPC. Przegląd tego orzecznictwa pokazuje, że organy w Strasburgu w pierwszej kolejności oceniły dopuszczalność skazania nieletniego sprawcę na powyższą karę, następnie odniosły się do kwestii dopuszczalności deportacji osoby z Państwa-Strony EKPC do państwa, w którym istnieje rzeczywiste ryzyko skazania na taką karę i wreszcie ustaliły warunki skazania na taką karę dorosłego sprawcę. Ze względu na ograniczone ramy artykułu dwie pierwsze kwestie orzecznictwa zostały pominięte.

Odpowiedzi na postawione pytania badawcze wydają się mieć nie tylko wartość teoretyczną, ale także praktyczną, ponieważ umożliwiają ocenę zmian w polskim prawie karnym z 2019 r. w zakresie dożywotniego pozbawienia wolności bez możliwości warunkowego zwolnienia. 
The Paradigm of the Prohibition of Ill-Treatment in the Context of Life Imprisonment (Article 3 of the European Convention on Human Rights)

\section{Summary}

The framework of the analysis conducted in this article is based on three multifaceted research problems. The first one is related to the complex structure of the prohibition of ill-treatment and the degree of its absoluteness: the prohibition is unqualified and unconditional. The second concerns the material scope of the rights of persons sentenced to absolute imprisonment. The third problem deals with the structure and nature, content (subject matter) and means of performing the obligations of the State Party, correlated with these rights.

These three research problems focus on the ECHR on absolute imprisonment under the Art. 3 of the ECHR. A review of the case-law shows the Strasbourg bodies first assessed the compatibility of sentencing a minor offender to the above sentence, then addressed the issue of the admissibility of deportation a person from a State Party to the ECHR to a State, where there is a real risk of being sentenced to such a sentence and finally determined the conditions for sentencing the adult offender to such a sentence.

Due to limited framework of the article, the first two issues are not discussed in the article.

The answers to these research questions seem to have not only theoretical but also practical aspect as they make it possible to assess the changes in Polish criminal law of 2019 with regard to life imprisonment without the possibility of parole.

Słowa kluczowe: europejska Konwencja praw człowieka; zakaz poniżającego traktowania i karania; bezwzględna kara dożywotniego pozbawienia wolności; prawo do szansy na zwolnienie; prawo prawa do możliwości weryfikacji zasadności jej dalszego odbywania; resocjalizacja skazanego na dożywocie. 
Keywords: European Convention on Human Rights; prohibition of degrading treatment and punishment; an absolute sentence to life imprisonment; prospect of early release; possibility of review; social rehabilitation of prisoners serving life sentences.

\section{Bibliografia}

Balcerzak M., Odpowiedzialność państwa-strony europejskiej konwencji o ochronie praw człowieka i podstawowych wolności. Studium prawnomiędzynarodowe, Toruń 2013.

Borski M., Miejsce umów międzynarodowych w porządku prawnym Rzeczypospolitej Polskiej, «Rocznik Administracji i Prawa»16/2016, s. 17-32.

Capotorti F., Human Rights: The Hard Road Towards Universality, [w:] The Structure and Process of International Law: Essays in Legal Philosophy Doctrine and Theory, eds. R.ST.J. MacDonald, D.M. Johnston, Dordrecht-Boston-London 1991, s. 977-1000.

CAssese A., Prohibition of Torture and Inhuman or Degrading Treatment of Punishment, [w:] The European System for the Protection of Human Rights, eds. R.St.J. Macdonald, F. Matscher, H. Petzold, Dordrecht 1993, s. 225-262. Ciepey F., O dowartościowanie retrybutywnej racjonalizacji kary, [w:] 'Hominum causa omne ius constitutum est'. Księga jubileuszowa ku czci Profesor Alicji Grześkowiak, red. A. DęBIński, M. Ga£ĄzKa, R.D. Ha£as, K. Wiak, Lublin 2006, s. 231-246.

Colandrea V., On the Power of the European Court of Human Rights to Order Specific Nonmonetary Measures, «Human Rights Law Review» 7/2007, s. 396-411.

Djefal C., Static and Evolutive Treaty Interpretation. A Functional Reconstruction, Cambridge 2016.

Drzemczewski A.Z., European Human Rights Convention in Domestic Law: a Comparative Study, Oxford 1983.

Dyer A., Irreducible Life Sentences: What Difference have the European Convention on Human Rights and the United Kingdom Human Rights Act Made?, «Human Rights Law Review» 16.3/2016, s. 541-584.

Fellmeth A.X., Paradigms of International Human Rights Law, Oxford 2016. FitzPatrick J., Speaking Law to Power: The War against Terrorism and Human Rights, «European Journal of International Law» 14.2/2003, s. 241-264. GAAY ForTMAN B. DE, Equal dignity in international human rights law, [w:] The Cambridge Handbook of Human Dignity. Interdisciplinary Perspectives, eds. M. Düwell, J. bra arvig, R. Brownsword, D. Mieth, Cambridge 2014. 
Gardocka T., Opinia zewnętrzna. Autor wskazany przez poset Barbarę Dolniak, wicemarszałek Sejmu RP. Ekspertyza dotycząca zmian w kodeksie karnym (druk nr 3451 oraz tekst przekazany do Senatu po uchwaleniu przez Sejm 16 maja 2019 roku), http://www.sejm.gov.pl/sejm8.nsf/opinieBAS. xsp?nr=3451 (dostęp 12 grudnia 2019 r.).

Garlicki L., Kondak I., Poland. Human rights between international and constitutional law, [w:] The Impact of the ECHR on Democratic Change in Central and Eastern Europe, eds. I. Мотос, I. Ziemele, Cambridge 2016, s. 306-310.

Hedigan J., The European Convention on Human Rights and Counter-Terrorism, «Finish Journal of International Law» 28.2/2004, s. 392-431.

Hermida del Llano C., Argumentation of the Court of Strasbourg's Jurisprudence regarding the discrimination against Roma, «Przegląd Prawa Konstytucyjnego» 6.28/2015, s. 11-38.

Jasudowicz T., Sprawa Kudła v. Poland z 2000 r.: zasada godności człowieka w porzadku prawnym Europejskiej Konwencji Praw Człowieka, [w:] Polska przed Europejskim Trybunałem Praw Człowieka. Sprawy wiodące: sprawa Kudła przeciwko Polsce z 2000 r., red. E.H. Morawska, Warszawa 2019, s. 21-41.

KNox J.H., Horizontal Human Rights Law, «American Journal of International Law»102/2008, s. 1-41.

Kuteynikov A., Boyashov A., Dignity before the European Court of Human Rights, [w:] Human dignity. Establishing Worth and Seeking Solutions, eds. E. SieH, J. McGregor, London 2017, s. 93-104.

KwIEcień R., Suwerenność państw: rekonstrukcja i znaczenie idei w prawie międzynarodowym, Kraków 2004.

Luban D., Treatment of prisoners and torture, [w:] The Cambridge Handbook of Human Dignity. Interdisciplinary Perspectives, eds. M. DüWELL, J. BRAARvig, R. BRownsword, D. Mieth, Cambridge 2014, s. 446-454.

MejJer S., Rehabilitation as a Positive Obligation, «European Journal of Crime, Criminal Law and Criminal Justice» 25/2017, s. 145-162.

Moravcsiк A., The Origins of Human Rights Regimes: Democratic Delegation in Postwar Europe, «International Organization» 54.2/2000, s. 217-252.

Morawska E.H., Sprawa Kudła v. Poland z 2000 r.: typy zobowiązań pozytywnych państw stron europejskiej Konwencji praw człowieka w warunkach detencji (art. 3 konwencji), [w:] Polska przed Europejskim Trybunałem Praw Człowieka. Sprawy wiodące: sprawa Kudła przeciwko Polsce z 2000 r., red. E.H. Morawska, Warszawa 2019, s. 41-64. 
Morawska E.H., The complex structure of the absolute prohibition of torture. Comments in the light of the regulation of article 3 of the European Convention on Human Rights, «Espaço Jurídico: Journal of Law» 17.3/2016, s. 767-778.

MoRAwska E.H., Zobowiazania pozytywne państw-stron konwencji a ochrona praw człowieka i podstawowych wolności, Warszawa 2016.

Mowbray A., The Development of Positive Obligations under the European Convention on Human Rights by the European Court of Human Rights, Oxford 2004.

O'MAHony C., There is no such thing as a right to dignity, «International Journal of Constitutional Law» 10.2/2012, s. 551-574.

Peters A., Humanity as the $A$ and $\Omega$ of Sovereignty, "European Journal of International Law» 20.3/2009, s. 513-544.

Reus-Smit C., Individual Rights and Making of International System, Cambridge 2013.

SMET S., The 'Absolute" prohibition of torture and inhuman or degrading treatment in Article 3 ECHR: truly a question or scope only?, [w:] Shaping Rights in the ECHR. The Role of the European Court of Human Rights in determining the Scope of Human Rights, eds. E. Brems, J. Gerards, Cambridge 2014, s. 273-293.

Smit van Zyl D., Weatherby P., Creighton S., Whole Life Sentences and the Tide of European Human Rights Jurisprudence: What Is to Be Done?, «Human Rights Law Review» 14/2014, s. 59-84.

Spano R., Deprivation of Liberty and Human Dignity in the Case-Law of the European Court of Human Rights, «Bergen Journal of Criminal Law and Criminal Justice» 4.2/2016, s. 150-166.

Tомuschat CH., International Law: Ensuring the Survival of Mankind on the Eve of a New Century. General Course on Public International Law, «Recueil des Cours: Collected Courses of the Hague Academy of International Law» 281/1999, s. 9-438.

Vermeulen B., Freedom from Torture and Other Inhuman or Degrading Treatment or Punishment, [w:] Theory and Practice of The European Convention on Human Rights ${ }^{4}$, eds. P. van Dijk, F. van Hoof, A. van RiJn, L. ZWAAK, Antwerpen-Oxford 2006, s. 309-333.

WAR BRICK C., The European Response to Terrorism in an Age of Human Rights, «European Journal of International Law» 15.5/2004, s. 989-1018.

WiśNIEWSKi A., Uwagi o zastosowaniu standardów strasburskich w sprawach dotyczacych ochrony dóbr osobistych (na tle ostatnich orzeczeń ETPC w sprawach przeciwko Polsce), «Gdańskie Studia Prawnicze» 39/2018, s. 73-85.

Xenos D., The Positive Obligations of the State under the European Convention of Human Rights, London 2011. 